\title{
HUBUNGAN FAKTOR GENETIK DENGAN TEKANAN DARAH PADA REMAJA
}

\author{
${ }^{1}$ Jane A. Kalangi \\ ${ }^{2}$ Adrian Umboh \\ ${ }^{2}$ Vivekenanda Pateda
}

\author{
${ }^{1}$ Kandidat Skripsi Fakultas Kedokteran Universitas Sam Ratulangi Manado \\ ${ }^{2}$ Bagian Ilmu Kesehatan Anak Universitas Sam Ratulangi Manado \\ Email: kalangijane@gmail.com
}

\begin{abstract}
Essential hypertension is more commonly found in adolescent than in younger children and is strongly associated with genetic factor and obesity. Genes that play important role in hypertension mechanism are classified into genes that affect the natrium homeostasis in kidney, which include the I/D polymorphism ACE (Angiotensin Converting Enzyme) gene, and genes that affect steroid metabolism. Adolescents with hypertensive parents have higher risk of developing hypertension than those without familial history of hypertension. The aim of this research is to study the relationship between genetic factor (family history of hypertension) and blood pressure of adolescents. This was an analytic observational study with a cross sectional design. It was conducted in November- December 2014 at SMP Negeri 8 Malalayang. Samples were students with good nutritional status who are registered in that particular school and are given permission by their parents to participate in the study. There were 80 students who were involved in the study. Questionnaires were distributed to the students to know the existence of family history of hypertension especially in their parents and then the students' blood pressure were measured. The data obtained is analyzed using Fisher's Exact Test with SPSS program. The results showed that according to Fisher's Exact Test, there was no significant relationship between genetic factor and blood pressure in adolescent. $(p=0.154>0.05)$. Conclusion: There was no relationship between genetic factor (hypertensive parents) and blood pressure in adolescent.
\end{abstract}

Keywords: genetic factor, blood pressure, hypertension, adolescent

\begin{abstract}
Abstrak: Hipertensi esensial lebih sering ditemukan pada remaja dibandingkan dengan anak-anak dan dikaitkan erat dengan faktor genetik dan obesitas. Gen-gen yang berperan dalam mekanisme hipertensi dibagi menjadi gen yang mempengaruhi homeostasis natrium di ginjal, termasuk polimorfisme I/D gen ACE (Angiotensin Converting Enzyme) dan gen yang mempengaruhi metabolisme steroid. Remaja dengan orangtua hipertensif mempunyai resiko untuk mendapat hipertensi lebih tinggi dibandingkan anak dengan orangtuanya yang normotensif. Tujuan dari penelitian adalah untuk mengetahui hubungan faktor genetik (riwayat hipertensi dalam keluarga) dengan tekanan darah. Penelitian ini bersifat observasional analitik dengan rancangan potong lintang. Penelitian ini dilakukan pada bulan November - Desember 2014 di Sekolah Menengah Pertama Negeri 8 Malalayang. Sampel penelitian yaitu siswa yang memenuhi kriteria inklusi yaitu anak dengan status gizi baik yang tercatat di register sekolah serta mendapat izin dari orangtua untuk mengikuti penelitian. Subjek penelitian berjumlah 80 siswa. Kuesioner dibagikan untuk mengetahui riwayat hipertensi dalam keluarga terutama pada orang tua lalu tekanan darah anak diukur. Data yang diperoleh dianalisa menggunakan Fisher's Exact Test dengan bantuan program SPSS. Hasil penelitian menunjukkan bahwa berdasarkan uji Fisher's exact, tidak terdapat hubungan yang signifikan antara faktor genetik (riwayat hipertensi dalam keluarga) dengan tekanan darah pada remaja (nilai $\mathrm{p}=0,154>0.05$ ). Simpulan: Tidak terdapat hubungan antara faktor genetik (orang tua yang hipertensi) dengan tekanan darah pada remaja

Kata kunci: faktor genetik, tekanan darah, hipertensi, remaja
\end{abstract}


Hipertensi pada remaja didefinisikan sebagai rerata tekanan darah sistolik (TDS) dan tekanan darah diastolik (TDD) $\geq$ persentil 95 pada jenis kelamin, usia, tinggi badan yang sesuai pada 3 kali pengukuran berbeda. $^{1}$ Studi oleh Falkner et al, menunjukkan prevalensi hipertensi pada remaja sekitar $1-5 \%{ }^{2}$ Menurut hasil RISKESDAS 2013, prevalensi nasional hipertensi di Indonesia pada remaja (15-17 tahun) yaitu $5,3 \% .^{3}$ Hipertensi dibagi menjadi hipertensi primer dan sekunder. Hipertensi primer disebut juga hipertensi esensial dimana penyakit yang mendasari tidak diketahui adanya. Hipertensi esensial lebih sering ditemukan pada remaja dibandingkan anak-anak, dan sering dikaitkan dengan beberapa faktor lainnya, seperti obesitas dan faktor genetik. ${ }^{4}$

Gen-gen yang berperan dalam mekanisme hipertensi yaitu gen yang mempengaruhi homeostasis natrium di ginjal, termasuk polimorfisme I/D (insersi/delesi) gen ACE (angiotensin converting enzyme), dan gen yang mempengaruhi metabolisme steroid. Studi menyatakan polimorfisme I/D gen ACE dapat menghasilkan 3 genotip : II homozigot, ID heterozigot dan DD Homozigot. Individu dengan DD homozigot mempunyai konsentrasi ACE yang lebih tinggi dibandingkan dengan yang lain. Dengan konsentrasi ACE yang lebih tinggi maka konsentrasi angiotensin II juga meningkat. Angiotensin II yang tinggi dapat menyebabkan peningkatan tekanan darah secara progresif melalui 2 mekanisme: vasokonstriksi di arteri perifer dan penurunan ekskresi garam dan air oleh ginjal. $^{5-7}$

Remaja dengan riwayat keluarga hipertensi mempunyai risiko lebih tinggi untuk menderita hipertensi dibandingkan dengan remaja dengan keluarga tanpa hipertensi. ${ }^{8}$ Studi oleh Singh, sekitar 30$60 \%$ variasi pada tekanan darah di berbagai individu disebabkan oleh efek faktor genetik. ${ }^{9}$ Anak yang mempunyai riwayat keturunan hipertensi pada kedua orangtuanya mempunyai risiko 40-60 \% hipertensi ketika beranjak dewasa. ${ }^{8}$ Studi oleh Miyao dan Furusho menemukan jika kedua orangtua penderita hipertensi, maka insidensi hipertensi pada anak meningkat 4 sampai 15 kali dibandingkan dengan anak yang kedua orangtuanya normotensif: ${ }^{10}$

Berdasarkan latar belakang masalah tersebut, penulis melakukan penelitian untuk mengetahui hubungan faktor genetik dengan tekanan darah pada remaja di SMP Negeri 8 Malalayang.

\section{METODE PENELITIAN}

Jenis penelitian yang digunakan ialah observasional analitik dengan rancangan potong lintang. Waktu penelitian dilakukan pada bulan November - Desember 2014. Tempat penelitian dilakukan di SMP Negeri 8 Malalayang. Populasi adalah seluruh siswa SMP Negeri 8 Malalayang. Sampel penelitian berjumlah 80 siswa diambil berdasarkan kriteria inklusi yaitu : siswa dengan status gizi baik yang tercatat dalam register sekolah dan diizinkan oleh orang tua untuk mengikuti penelitian. Kuesioner dibagikan kepada murid kelas 7 \& 8 untuk mengetahui riwayat hipertensi dalam keluarga (terutama orang tua), lalu tekanan darah anak diukur. Analisis data dilakukan dengan uji Fisher's Exact menggunakan program SPSS.

\section{HASIL PENELITIAN}

Untuk memperoleh gambaran distribusi berdasarkan karakteristik responden dapat dilihat pada tabel 1 .

Tabel 1. Distribusi sampel berdasarkan umur

\begin{tabular}{ccc}
\hline Umur & Frekuensi & Persentase (\%) \\
\hline 11 & 9 & 11,3 \\
12 & 40 & 50 \\
13 & 28 & 35 \\
14 & 3 & 3,8 \\
\hline
\end{tabular}

Tabel 1 menunjukkan bahwa 11,3\% responden berumur 9 tahun, 50\% responden berumur 12 tahun, 35\% responden berumur 13 tahun dan 3,8\% responden berumur 14 tahun. 
Tabel 2. Distribusi sampel berdasarkan tekanan darah

\begin{tabular}{ccc}
\hline $\begin{array}{c}\text { Tekanan } \\
\text { darah }\end{array}$ & Frekuensi & $\begin{array}{c}\text { Persentase } \\
(\%)\end{array}$ \\
\hline Normal & 71 & 88,8 \\
Hipertensi & 9 & 11,2 \\
\hline
\end{tabular}

Tabel 2 menunjukkan bahwa 88,8 \% dari responden mempunyai tekanan darah normal dan 11,2\% mempunyai hipertensi. Dalam studi ini, kelompok prehipertensi (rerata TDS \& TDD $\geq$ persentil 90 dan < persentil 95) dimasukkan dalam kelompok hipertensi.

Tabel 3. Distribusi sampel berdasarkan riwayat hipertensi

\begin{tabular}{ccc}
\hline $\begin{array}{c}\text { Riwayat } \\
\text { Hipertensi }\end{array}$ & Frekuensi & $\begin{array}{c}\text { Persentase } \\
\text { (\%) }\end{array}$ \\
\hline Positif & 40 & 50 \\
Negatif & 40 & 50 \\
\hline
\end{tabular}

Tabel 3 menunjukkan 50\% responden mempunyai riwayat hipertensi positif (satu atau kedua orangtua yang hipertensi) dan $50 \%$ responden lainnya mempunyai riwayat hipertensi negatif.
Tabel 4. Distribusi Tekanan darah sistolik berdasarkan riwayat hipertensi

\begin{tabular}{ccc}
\hline \multirow{2}{*}{$\begin{array}{c}\text { Riwayat } \\
\text { hipertensi }\end{array}$} & \multicolumn{2}{c}{ Tekanan darah sistolik } \\
\cline { 2 - 3 } & $\begin{array}{c}\text { Normal } \\
(\%)\end{array}$ & $\begin{array}{c}\text { Hipertensi } \\
(\%)\end{array}$ \\
\hline Positif & $33(41,3)$ & $7(8,7)$ \\
Negatif & $38(47,5)$ & $2(2,5)$ \\
Jumlah & $71(88,8)$ & $9(11,2)$ \\
\hline
\end{tabular}

Tabel 4 menunjukkan bahwa hipertensi (tekanan darah diastolik) ditemukan pada 8,7\% responden dengan riwayat hipertensi positif dan 2,5\% responden dengan riwayat hipertensi negatif.

Tabel 5. Distribusi tekanan darah diastolik berdasarkan riwayat hipertensi

\begin{tabular}{ccc}
\hline Riwayat hiper & \multicolumn{2}{c}{ Tekanan darah diastolik } \\
\cline { 2 - 3 } tensi & Normal(\%) & Hipertensi(\%) \\
\hline Positif & $36(45)$ & $4(5)$ \\
Negatif & $39(48,8)$ & $1(1,2)$ \\
Jumlah & $71(93,8)$ & $9(6,2)$ \\
\hline
\end{tabular}

Tabel 5 menunjukkan bahwa hipertensi (tekanan darah diastolik) ditemukan pada 5\% responden dengan riwayat hipertensi positif dan 1,2\% responden dengan riwayat hipertensi negatif.

Tabel 6. Hubungan riwayat hipertensi dengan tekanan darah responden

\begin{tabular}{ccccc}
\hline Riwayat & \multicolumn{2}{c}{ Tekanan darah } & Total & Fisher's exact \\
Hipertensi & Normal & Hipertensi & $(\%)$ & p-value \\
& $(\%)$ & $(\%)$ & & 0,154 \\
\hline Positif & 33 & 7 & $\mathbf{4 0}$ & \\
& $(41,3)$ & $(8,7)$ & $(50)$ & \\
Negatif & 38 & 2 & 40 & \\
& $(47,5)$ & $(2,5)$ & $(50)$ & \\
\hline
\end{tabular}

Berdasarkan tabel uji Uji Fisher Exact diatas nilai sig. sebesar 0,154. Hal ini menunjukkan bahwa nilai sig $>0,05$ (Tabel 6).

\section{BAHASAN}

Berdasarkan hasil analisa distribusi tekanan darah berdasarkan riwayat hipertensi, hipertensi lebih banyak ditemukan pada anak dengan riwayat hipertensi positif (8,7\%) dibandingkan dengan anak dengan riwayat hipertensi negatif (2,5\%).

Hasil analisis dengan Uji Fisher's Exact untuk mengetahui hubungan riwayat hipertensi dengan tekanan darah, menunjukkan tidak ada hubungan antara kedua variabel, dengan dasar nilai $\mathrm{p}>0,05$.

Hasil pada penelitian ini tidak sama dengan hasil penelitian sebelumnya oleh Toker, Malbora, dan Kuschnir et al yang menyatakan bahwa terdapat hubungan 
antara riwayat hipertensi yang positif dengan peningkatan insidensi hipertensi pada remaja. ${ }^{11-13}$ Hal ini dapat disebabkan karena populasi dan sampel yang kurang mencukupi dimana penelitian ini hanya dilakukan pada satu sekolah. Menurut penelitian oleh Henulili et al tentang pola pewarisan penyakit hipertensi dalam keluarga mengemukakan bahwa gen hipertensi bersifat dominan. ${ }^{14}$ Walaupun begitu menurut hukum Mendel, jika hanya salah satu orang tua menderita hipertensi, maka kemungkinan anaknya untuk tidak menderita hipertensi yaitu 50\%. Pada penelitian ini, hampir semua anak hanya mempunyai satu orangtua yang hipertensif. Maka dari teori tersebut, diambil kesimpulan kebanyakan dari anak-anak dengan salah satu orangtuanya hipertensif yang tidak hipertensi, alel dominan hipertensi tidak diwariskan kepada mereka. ${ }^{14}$

Beberapa penelitian telah menyatakan bahwa banyak sekali gen yang dapat mempengaruhi tekanan darah, namun pada pembahasan kali ini gen-gen tersebut dikelompokkan menjadi: gen yang mengenkode sistem renin-angiotensin (poilmorfisme I/D gen Angiotensinconverting enzyme), gen yang berperan dalam homeostasis natrium ginjal dan gen yang mengatur metabolisme steroid. ${ }^{5-7}$

Gen-gen yang berperan dalam homeostasis natrium di ginjal yaitu WNK-1 (gen lysine- deficient protein kinase 1), SNNN1B (amilorid-sensitive sodium channel), SCNN1G (gen subunit beta dan gamma yang mengenkode 2 subunit $\mathrm{ENaC}$ channel sodium). ${ }^{11}$ Gen-gen tersebut mempengaruhi pompa $\mathrm{Na}^{+}-\mathrm{K}^{+}$pada tubulus ginjal sehingga meningkatkan retensi natrium dan air pada ginjal. Dengan meningkatnya reabsorpsi natrium pada ginjal maka volume plasma dan cairan ekstrasel meningkat. Dengan begitu, volume ekstrasel meningkat dan menyebabkan peningkatan aliran darah balik vena ke jantung. Terjadilah peningkatan curah jantung dan selanjutnya peningkatan tekanan arteri. ${ }^{5-7}$
Gen-gen yang diduga berpengaruh pada metabolisme hormon steroid yaitu CYP11B2 (gen aldosteron synthase) dan NR3C2 (gen reseptor mineralokortikoid). Gen-gen tersebut meningkatkan produksi aldosteron sehingga nantinya akan meningkatkan retensi natrium di ginjal. Terjadi peningkatan curah jantung dan selanjutnya tejadi peningkatan tekanan arteri. $^{5-7}$

Polimorfisme insersi/delesi dari gen ACE (angiotensin - converting enzyme) dikarakteristikan dengan adanya atau hilangnya repeat sequence $28 \mathrm{bp}$ pada intron 16 dan merupakan gen yang juga diduga berperan kuat dalam mekanisme hipertensi. Polimorfisme gen tersebut menghasilkan 3 genotipe : II Homozigot, ID heterozigot, dan DD homozigot. Studi menyatakan individu homozigot dengan alel D mempunyai konsentrasi ACE yang lebih tinggi dibandingkan dengan individu heterozigot ID atau homozigot II. ${ }^{13}$ Dengan bertambahnya kadar ACE dalam darah dan jaringan, maka kadar Ang II (angiotensin II) juga meningkat. Dua pengaruh utama Angiotensin II dalam meningkatkan tekanan arteri yaitu vasokonstriksi di berbagai daerah di tubuh dan penurunan ekskresi garam dan ginjal oleh air. Dengan adanya vasokonstriksi di berbagai tempat, maka terjadi peningkatan tahanan perifer total yang selanjutnya meningkatkan tekanan arteri. Ang II juga berperan dalam reabsorpsi natrium dan air dari urin. Mekanisme terjadinya hipertensi sama dengan mekanisme hipertensi oleh gen yang berperan dalam homeostasis natrium di ginjal. $^{5-7}$

\section{SIMPULAN}

Dari hasil penelitian dapat disimpulkan bahwa tidak ada hubungan antara faktor genetik (orang tua yang hipertensi) dengan tekanan darah pada remaja.

\section{SARAN}

Berdasarkan hasil penelitian yang menunjukkan bahwa lebih banyak 
hipertensi pada anak dengan riwayat hipertensi positif maka dianjurkan bagi orang tua anak untuk melakukan pemeriksaan tekanan darah pada anak secara rutin minimal satu tahun sekali untuk mendeteksi adanya kenaikan tekanan darah yang abnormal.

\section{DAFTAR PUSTAKA}

1. National High Blood Pressure Education Program Working Group on High Blood Pressure in Children and Adolescent. The fourth report on the diagnosis, evaluation, and treatment of high blood pressure in children and adolescents. Pediatrics.2004;114:55576

2. Falkner B. Hypertension in children and adolescents: epidemiology and natural history. Pediatr Nephrol. 2010;25:1219-24

3. Badan Litbang Kesehatan Departemen Kesehatan RI Riset Kesehatan Dasar (RISKESDAS). Hipertensi di Indonesia. 2013

4. Berstein D. Sistem Kardiovaskuler. Dalam: Behrman RE, Kliegman RM, Arvin AM, Wahab AS, penyunting. Ilmu kesehatan anak Nelson. Edisi ke-15. Jakarta: EGC; 2000. p. 1544-52.

5. Ehret GB Caulfield MJ. Genes for blood pressure: an opportunity to understand hypertension. European Heart Journal. 2013;34:951-61

6. Sayed-Tabatabaei FA, Oostra BA, Isaacs A, Van Duijn CM, Witteman JCM. ACE Polymorphisms. Circ Res. 2006;98:1123-33

7. Zarouk WA, Hussein IR, Esmaeil NN,
Raslan HM, Reheim HAA, Moguib O, Emara NA, Aly AA, Hamed M. Association of angiotensin converting enzyme gene (I/D) polymorphism with hypertension and type 2 diabetes. Bratisl Lek Listy. 2012;113(1):14-8

8. Saing JH. Hipertensi pada remaja. Sari Pediatri. Maret 2005;6:159-65

9. Singh M, Mensah GA, Bakris G. Pathogenesis and clinical physiology of hypertension. Cardiol Clin. 2010;28(4):545-59 (Abstract)

10. Kher KK. Hypertension. Dalam: Kher KK, Makker SP, penyunting. Clinical Pediatric Nephrology. Singapore: McGraw-Hill International; 1992. p. 323-76

11. Toker RT, Yildirim A, Demir T, Ucar B, Kilic Z. Circardian blood pressure rhythm in normotensive offspring of hypertensive parents. Cardio J. July 2014. doi: 10.5603/CJ.a2014.0053.

12. Malbora B, Baskin E, Bayrakci US, Agras PI, Cengiz N, Haberal $M$. Ambulatory blood pressure monitoring of healthy school children with a family history of hypertension. Ren Fail. 2010;32(5):535-40.(Abstract)

13. Kuschnir MCC, Mendonca GAS. Risk factors associated with arterial hypertension in adolescents. J Pediatr (Rio J). 2007;83(4):335-42

14. Henulili V, Yuliati, Rahayu T, Nurkhasanah L. Pola pewarisan penyakit hipertensi dalam keluarga sebagai sumber belajar genetika. Prosiding Seminar Nasional Penelitian, Pendidikan dan Penerapan MIPA. 2011:B242-7 